\title{
Autographs of French Kings from the collection of Nikolay Likhachev
}

\section{E.I. Nosova}

For citation: Nosova E.I. Autographs of French Kings from the collection of Nikolay Likhachev. Vestnik of Saint Petersburg University. History, 2018, vol. 63, issue 2, pp. 432-446. https://doi. org/10.21638/11701/spbu02.2018.207

This article continues the study of the acts and letters of the King of France Louis XI (14611483), stored in the Scientific and Historical Archives of the St. Petersburg Institute of History RAS and originating from the collection of Nikolay Petrovich Likhachev (1862-1936). In the process of preparing documents for publication, the author had to face the problem of attribution of autographs. Since researchers have long known that some secretaries of Louis XI had the right to sign documents on behalf of the king, the authenticity of these signatures needs to be proven. The question of signature was traditionally developed in French historiography. So, in 2015 the work devoted to the birth and development of the signature in France in the Middle Ages was published. Among other things, the author examines autographs of Louis XI trying to solve the problem of the authorship of signatures. However, he does not always manage to come to any conclusion. We have tried to supply the method of palaeographic research used by the author by forensic handwriting expertise. The analysis showed that the handwriting of Louis $\mathrm{XI}$ can be called a medium-developed one. It is distinguished by the rhythm, the high degree of the motor skill and the regularity (consistent heights and widths). The signature of Louis XI can be attributed to the signatures of a complex design, which are not easy to imitate. At the same time, the royal secretaries, who had the right to imitate the King's handwriting, belonged to the category of high-level specialists, therefore, the signature they made differed only by insignifi-

Ekaterina I. Nosova - $\mathrm{PhD}$ in History, Researcher, St. Petersburg Institute of History of the Russian Academy of Sciences, 7, Petrozavodskaya ul., St. Petersburg, 197110, Russian Federation; katerinanossova@gmail.com

Екатерина Игоревна Носова - канд. ист. наук, научный сотрудник, Санкт-Петербургский институт истории РАН, Российская Федерация, 197110, Санкт-Петербург, Петрозаводская ул., 7; katerinanossova@gmail.com

This research was supported by the grant of the President of the Russian Federation for the young PhDs no. MK-5297.2018.6 "Letters and acts of French Kings in the Scientific Archives of St. Petersburg Institute of History $\left(14^{\text {th }}-15^{\text {th }}\right)^{\text {". }}$.

We express our deep gratitude to Denis Olegovich Tsypkin (St. Petersburg State University) for his assistance in the preparation of the article and to Sofia Igorevna Lobataya (Goethe University, Frankfurt am Main) for translation in English.

(C) Санкт-Петербургский государственный университет, 2018 
cant details. One of the brightest signs of imitation of the handwriting of another person is the reduction of the coordination of movements, which is manifested in the large and small sinuosity and angularity of strokes, prevalence of adhesions over conjoint elements, thickness at the beginnings and terminations of strokes, unjustified stops of a feather as well as undifferentiated pressing. All these characteristics were found in the autographs of Louis XI from the Scientific Archives of St. Petersburg Institute of History. Thus, it can be concluded with a certain degree of probability that these signatures didn't belong to the king himself.

Keywords: historical handwriting, palaeography, Louis XI, French Chancellery, forensic handwriting expertise, autographs, N. P. Likhachev.

\section{Автографы французских королей из коллекции Николая Петровича Лихачева}

\section{Е. И. Носова}

Для цитирования: Nosova E. I. Autographs of French Kings from the collection of Nikolay Likhachev // Вестник Санкт-Петербургского университета. История. 2018. Т. 63. Вып. 2. С. 432-446. https:// doi.org/10.21638/11701/spbu02.2018.207

Настоящая статья продолжает исследование актов и писем короля Франции Людовика XI (1461-1483), хранящихся в Научно-историческом архиве Санкт-Петербургского института истории РАН и происходящих из коллекции Николая Петровича Лихачева (1862-1936). В процессе подготовки документов к публикации автору статьи пришлось столкнуться с проблемой атрибуции автографов. Поскольку исследователям давно известно о наличии у Людовика XI секретарей с правом подписи документов за короля, принадлежность рассматриваемых подписей руке монарха нуждается в доказательстве. Проблема подписи традиционно разрабатывалась во французской историографии. Так, в 2015 г. вышла работа, посвященная зарождению и развитию подписи во Франции эпохи Средневековья. Среди прочего ее автор рассматривает автографы Людовика XI и пытается решить проблему определения авторства подписи. Однако ему далеко не всегда удается прийти к какому-либо заключению. Мы попытались дополнить используемую автором методику палеографического исследования разработками в области судебного почерковедения. Анализ показал, что почерк Людовика XI можно назвать средневыработанным. Его отличают ритмичность, сформированность двигательного навыка и регулярность (выдерживаются высота и ширина написания букв). Подпись Людовика XI можно отнести к подписям сложной конструкции, имитировать которую нелегко. Вместе с тем королевские секретари, которые имели право имитировать почерк короля, принадлежат к категории специалистов высшего разряда, поэтому выполненную ими подпись могут отличать лишь незначительные детали. Одним из ярчайших признаков подражания почерку другого лица является снижение координации движений, что проявляется в крупной и мелкой извилистости и угловатости штрихов, преобладании присоединений над слитным выполнением, тупых началах и окончаниях штрихов, необоснованных остановках пера, а также недифференцированном нажиме. При рассмотрении автографов из Научно-исторического архива СПбИИ РАН все эти признаки были обнаружены в подписях Людовика XI, что свидетельствует о том, что они не были выполнены самим королем.

Ключевые слова: историческое почерковедение, палеография, Людовик XI, французская канцелярия, судебно-почерковедческая экспертиза, автографы, Н. П. Лихачев.

While solving strictly practical tasks, one often faces the problems requiring not only to turn aside from an original research objective, but also to explore unexpected areas of knowledge. While preparing the publication of the letters and acts of the French king 
Louis XI, which are stored in the Scientific Archives of St. Petersburg Institute of History of the Russian Academy of Sciences ${ }^{1}$, we were guided by the recommendations of École nationale des chartes (Paris) which is one of the European leaders in the field of palaeography and diplomatics ${ }^{2}$. The existence or absence of autographs is one of the document's main characteristics. In total seventeen acts and letters were discovered: part of them were published on behalf of Louis XI, others were directly connected to his personality ${ }^{3}$. Five of them bear royal signatures. All five charters are devoted to different subjects and can be united only by the person who produced them. This is their short description:

1. [1470 $]$, 30 Juin - Amboise. Louis [XI], King of France informs Duke of Milan [Galeazzo Maria Sforza] that he had sent him two sighthounds. Original. Papier, $22 \times 25$, trace of red wax seal on reverse. Scientific Archives of the St. Petersburg Institute of History, Western Manuscripts. Collection 8, carton 331, $\mathrm{n}^{\circ} 23$. Provenance is unknown.

2. 1472, December - Dinechien, near Puybelliard. Louis [XI], King of France attests the donation of territories of Talmont and the castellanies of Curson, Olonne, La Chaulme, Châteaugauthier, Berrye, Bray et Brandois which had been already given to Philippe de Commynes. Original. Parchment, $62,5 \times 48,5$. Ibid. Collection 8 , carton $338, n^{\circ} 3$. Provenance: Noël Charavay, collection of Benjamin Fillon. Description: Catalogue des autographes et des documents historiques composant la collection de M.Étienne Charavay. Quatrième vente. 10 décembre 1901. Paris, 1901. P. 350. $\mathrm{n}^{\circ} 1213$; Inventaire des autographes et documents historiques réunis par M. Benjamin Fillon / par É. Charavay. 3 vols. Paris, 1878-1900. Vol.2. P. 13. nº 863.

3. $\left[1475^{5}\right], 4$ February — Paris. Louis [XI], King of France appoints Jean de Daillon, chevalier, seigneur du Lude, gouverneur de Dauphiné, et Yvon du Fou, sénéchal de Poitou, as ambassadors to King of Aragon [John II]. Original. Papier, $44 \times 30,5$, trace of red wax seal. Ibid. Collection 9, carton 338, $\mathrm{n}^{\circ}$ 5. Provenance: Noël Charavay. Copy: BNF, Ms. fr. 6964, fol. 52. Ed.: Lettres de Louis XI. Vol. V. P. 318-320.

4. 1479, July - Nemours. Louis [XI], King of France, grants territory of Pontarlier to Robert de Montgombry, gentilhomme of his household, and to his male heirs. Original. Parchment, $42 \times 24,5$. Ibid. Collection 9, carton 338, $n^{\circ} 4$. Provenance: Veuve Charavay. Description: Lot 161. Revue des autographes. 1898. n 215. P. 12.

5. $\left[1480^{6}\right], 16$ December - Le Plessis-du-Parc. Louis [XI], King of France asks seigneur du Lude, Governor of Dauphiné to come to him as soon as possible. Original. Papier, $21,5 \times 15$. Ibid. Collection 9, carton 338, $n^{\circ} 6$. Provenance: Noël Charavay. Ed.: Lettres de Louis XI. Vol. VIII. P. 333.

${ }^{1}$ Nosova E. I. Chartes et lettres inédites de Louis XI (1461-1483) aux Archives de l'Institut d'histoire de Saint-Pétersbourg // Bulletin de la Société de l'histoire de France. An. 2014. Paris, 2018. P. 41-68.

2 Conseils pour lédition des textes médiévaux. 3 fasc. Genève, 2001-2002.

${ }^{3}$ No fewer than six signatures of Louis XI are also available at the Department of Manuscripts of the Russian National Library. Katalog pisem gosudarstvennykh i politicheskikh deyateley Frantsii XV v. iz sobraniya P.P.Dubrovskogo / eds T.P. Voronova, Y.P. Malinin. Saint-Petersburg, 1993. P.9-12. However, as the starting point of this study was the preparation for the publication of materials from the holdings of the Scientific Archives of St. Petersburg Institute of History of the Russian Academy of Sciences, we concentrated precisely on these specimens.

${ }^{4}$ Dated according to: Pièces fugitives, pour servir à l'histoire de France. Paris, 1759. Vol. I. Pt. I. P. 96.

5 Dated according to: Lettres de Louis XI, roi de France / éd. par J. Vaesen, É. Charavay et B. de Mandrot. 11 vols. Paris, 1883-1909. Vol. V. P. 318-320.

${ }^{6}$ Dated according to: Lettres de Louis XI. Vol. VIII. P. 333. 
Thus, documents cover a decade from 1470 to 1480, with time gaps between them no more than 4 years. Two of five charters are written on parchment and the others on paper.

As it was mentioned above, these five documents were signed by King of France Louis XI. At the same time, researchers have long discussed the fact of Louis XI's special secretaries who had the right to sign documents on the king's behalf (secrétaire de la main) ${ }^{7}$. It is hard to say who the first one to point to this fact was. Michel François attributes this statement to Brantôme ${ }^{8}$. Anyway, that Louis XI had a secretary who had the right to imitate royal handwriting was confirmed by Louis XI himself in one of the letters sent to his counsellor Ymbert de Batarnay. By this letter the King ordered Batarnay to "write the letter as if by my hand, as it's customary to do"'. The need for a person, who the King placed such a degree of trust in, can probably be put down to a sharp increase in the amount of work in the French royal chancellery. In the $14^{\text {th }}-15^{\text {th }}$ centuries it was producing about fifteen thousand documents a year. Despite the fact that the tradition of authentication of documents by personal signature only started to emerge during this period, and that the seal remained the principal instrument of authentication and validation of the document, the number of signatures of Louis XI's reign, exceeds imagination ${ }^{10}$. If we exclude the copies and documents concerning the king's person, which cannot bear his own autographs, from our selection, then more than a half of the documents are certified by his signature ${ }^{11}$. Considering the general growth in the number of documents coming from the royal chancellery, the emergence of a secretary with the right to sign on king's behalf is more than logical.

The study devoted to origins and development of the signature in France in the Middle Ages was published in $2015^{12}$. Its author, the graduate of École nationale des chartes, traces the origins of this phenomenon, correlating the signature with similar objects: monograms, signatures of notaries and witnesses, as well as with seals, which despite their striking difference from the signature, served the same function of authentication of the document. Then the author proceeds to describe the autographs of the French princes of blood and other monarchs (in particular, kings of England and the Iberian Peninsula), rightly observing the transformation of the status of the royalty and political culture in the change of signatures.

Claude Jeay dedicates a whole chapter to Louis XI's autographs, and using these samples he attempts to solve the problem of secrétaire de la main and to determine when the

7 Musée des Archives Nationales. Paris, 1872. P. 273.

${ }^{8}$ François M. Les signatures de Louis XI // Bulletin philologique et historique. 1959. P. 222.

9 Escripvez la lettre de ma main ainsi que accoutumé de faire... // Lettres de Louis XI. Vol. XI. P. VI.

${ }^{10}$ It is difficult to estimate the exact number because the publication of Louis XI's letters do not include charters, which were also sometimes verified with a royal signature, and only a few charters were included in the registers of the royal chancellery. Schreurer R. L'enregistrement à la chancellerie de France au cours du XVe siècle // Bibliothèque de l'École des chartes. 1962. N. 120. P. 104-129.

${ }_{11}$ Among the documents of Louis XI in the Department of Manuscripts of the Russian National Library more than a half bear the signature of the King. Katalog pisem... P.9-12. - It is difficult to assess whether these two corpus are representative as the documents originated from the former private collections of P. P. Doubrovsky (Department of Manuscripts of the Russian National Library) and N.Likhachev (Scientific Archives of St. Petersburg Institute of History of the Russian Academy of Sciences), considering that their owners purposefully searched for the autographs of famous people. However, judging by the collections of documents digitized by the French National Library, the signature of Louis XI is by no means a rarity.

12 Jeay C. Signature et pouvoir au Moyen Âge. Paris, 2015. Until 2015, a classic study on the problem of signature in France was the research of B. Fraenkel: Fraenkel B. La signature: genèse d'un signe. Paris, 1992. 
authorship belongs to the king or to his secretary. Despite the fact that the research is based on a large number of documents, it is difficult to come to any conclusion. In some cases, very similar signatures are attributed to different persons, and the author doesn't elaborate on the reasons behind such division. In our opinion, in this case the problem lies in the practice of using methods developed in palaeography and aimed at solving other tasks. In particular, the main attention is paid to a ductus and the module. The secretary's signature which accompanies the royal autograph ${ }^{13}$, serves as an additional argument: if the letter is signed by the secretary who had the right to imitate the royal signature, then the chances that signature belonged not to the king, but to his secretary, increase. However, the ductus of all five signatures from Scientific Archives of St. Petersburg Institute of History vary poorly and cannot serve as reliable criteria for the attribution. The same can be said about the module. As for the secretary, Claude Jeay has found himself a number of cases when the document was drawn by one secretary, while the king's signature was imitated by another one.

The circumstances of creation of the letter are much more helpful. For example, in the case of aforementioned Louis XI's letter to Ymbery de Batarnay, his counsellor. The king ordered Batarnay to write a letter of credence "as if my hand" for monsieur de Lombes, who was going to the queen of Castile. The author concludes that such an angular and large signature could have belonged only to Louis XI. In fact, it can't have belonged to Ymbert de Batarnay as the message was addressed to him. The author also excludes other secretaries by comparison of their signatures on behalf of the king, which were identified earlier. Thus, there are no other candidates left except for the king. However, situations where such meticulous analysis can be done are rare, if not singular.

Is it possible to use some other methods of analysis that differs from a purely paleographic one applied by the author? We have turned to the latest developments of those experts who traditionally face the task of differentiation of original signatures from their imitations- to methods applied by the experts in the field of handwriting analysis and forensic document examination. Perhaps, the solution proposed in the present article could be regarded as insufficiently substantiated. Nevertheless, is should be taken into account, first of all, that it is merely an attempt to search for an alternative method under the circumstances when traditional methods don't bring the desired results. Secondly, we rely on the experience of St. Petersburg school of Russian handwriting examination, based on psychophysiology, which has already proved the efficacy of this approach in the solution of various tasks ${ }^{14}$.

${ }^{13}$ In the French chancellery the secretary usually left a note at the end of the charter, in which he informed the chancellor who commanded him to draw up the present document. Without such a note certified by a signature of the secretary the chancellor could not seal the document. By applying his signature, the secretary took responsibility for the correct composition of the charter. In personal correspondence we see only the signature of the secretary in the lower part of a document, without any mentioning of those who ordered it. Morel $O$. La grande chancellerie royale et l'expédition des lettres royaux de l'avènement de Philippe de Valois à la fin du XIVe siècle (1328-1400). Paris, 1900. P. 157-159; Tessier G. Diplomatique royale française. Paris, 1962. P. 286-287.

14 Burdanova V.S., Sysoyeva L.A., Tsypkin D.O. K voprosu ob istorii russkoy podpisi // Vestnik Sankt-Peterburgskogo universiteta MVD Rossii. 1999. N1. P.118-121; Tsypkin D. O.: 1) Neskol'ko predvaritel'nykh zamechaniy o yedinstve ekspertnoy nauki i o problemakh sovremennogo istochnikovedeniya // Fotografiya. Izobrazheniye. Dokument. 2012. Iss. 3(3). P. 3-7; 2) Problema razrabotki yedinoy metodologicheskoy sistemy identifikatsii pishushchego v izuchenii drevnerusskikh rukopisno-knizhnykh pamyatnikov (na materiale Sofiyskogo, Kirillo-Belozerskogo i Solovetskogo sobraniy OR RNB. Istoriya i kul'tura 
Above all, it is necessary to have a reliable comparative material to conduct a research - an original authentic sample of autograph of Louis XI which will be compared to the available documents. In most cases the fact that the signature belongs to the king is proven by its cohesion (coherent handwriting and ink color) with the main text of the document or with several lines added at the end. Also, such inscriptions as "written by my hand" ("escript de ma main") ${ }^{15}$ can serve as an indication. Today historians know six letters, written entirely by Louis XI, and about a dozen lines attributed to him at the end of the messages drawn up by the secretaries. It is possible to carry out the analysis on the basis of these samples. The largest and indisputably authentic letter (Fig. 1-2) ${ }^{16}$ is the one which was written entirely by Louis' hand, dated 1460, and addressed to Giovanni Arnolfini (apprx. 1400-1472).

Arnolfini, a rich dealer and banker from Lucca, delivered fabrics to Dauphin of France, regardless of his dismal situation ${ }^{17}$. As follows from the text of the letter, it was written by the hand of Louis XI himself. Physical indicators, such as ink color and thickness of a feather, suggest that the signature makes a coherent whole with the main text. Therefore, it was made by the same person who wrote the main text. Finally, in 1460 Louis was still a Dauphin and didn't have to sign such a large number of papers to be in the need of hiring someone to do it on his behalf. Thereby, among the documents related to this period, authentic autographs of Louis $\mathrm{XI}^{18}$ are most likely to be found. Thus, the letter to Arnolfini can be taken as a sample ${ }^{19}$. A distinct feature of this sample is that Louis XI was 37 years old in 1460 , so he was an adult who had completed his education. This means that the handwriting of this sample does not have the character of an emerging one, which can be observed in the immature handwriting of young people, but is not yet subject to senile changes.

The following step is to consider and estimate Louis XI's handwriting, in general, and his signature, in particular. It is possible to characterize king's handwriting as mature. It is distinguished by the rhythm, developed motor skill, regularity (height, width), without any twisting shivering lines. The letter is characterized by high coherence (3-4 ele-

// Stat'i. Issledovaniya. Soobshcheniya. Iss. 11. St. Petersburg, 2013. P. 225-242; 3) Ob izuchenii istoricheskogo pis'ma na kafedre istorii zapadnoyevropeyskoy i russkoy kul'tury Instituta istorii SPbGU // Istoriya i kul'tura. Issledovaniya. Stat'i. Soobshcheniya. Publikatsii. Iss. 14. St. Petersburg, 2016. P. 226-236; 4) Ponyatiye pocherka $\mathrm{v}$ izuchenii russkogo istoricheskogo pis'ma: k probleme razrabotki metodologii pocherkovedcheskogo analiza drevnerusskikh rukopisey // Trudy Otdela drevnerusskoy literatury. Vol.64. St. Petersburg, 2016. P. 836-881; Sysoyeva L. A., Tsypkin D. O. Yeshche raz k voprosu o sovremennykh issledovaniyakh podpisi // Ekspert-kriminalist. 2016. N.2. P.22-24; Tsypkin D. O. Na puti k yedinomu ucheniyu o pocherke // Biblioteka kriminalista. Nauchnyy zhurnal. 2016. N3 (26). P.349-361.

${ }^{15}$ However, this instruction should be treated with caution since there are cases when Louis XI asked his secretary to write a letter imitating his hand ("by his hand"). It is not ruled out that this phrase could have migrated to the letter written under this order.

16 Bibliothèque nationale de France (BNF). Ms. fr. 20855. N 25. We express our deep gratitude to Anna Alexandrovna Maizlish (Institute of World History of the Russian Academy of Sciences) for an electronic copy.

17 Lassalmonie J.-Fr. La boîte à l'enchanteur: Politique financière de Louis XI. Vincennes, 2002. P. 46.

18 The documents of the Dauphin Louis can also be found in Scientific Archives of St. Petersburg Institute of History, but they are not signed. Nosova E. I. Chartes et lettres... N 1, 2.

${ }_{19}$ Other specimens ascribed to Louis XI either remained unavailable to us, or caused suspicions about their attribution to the King's hand. 


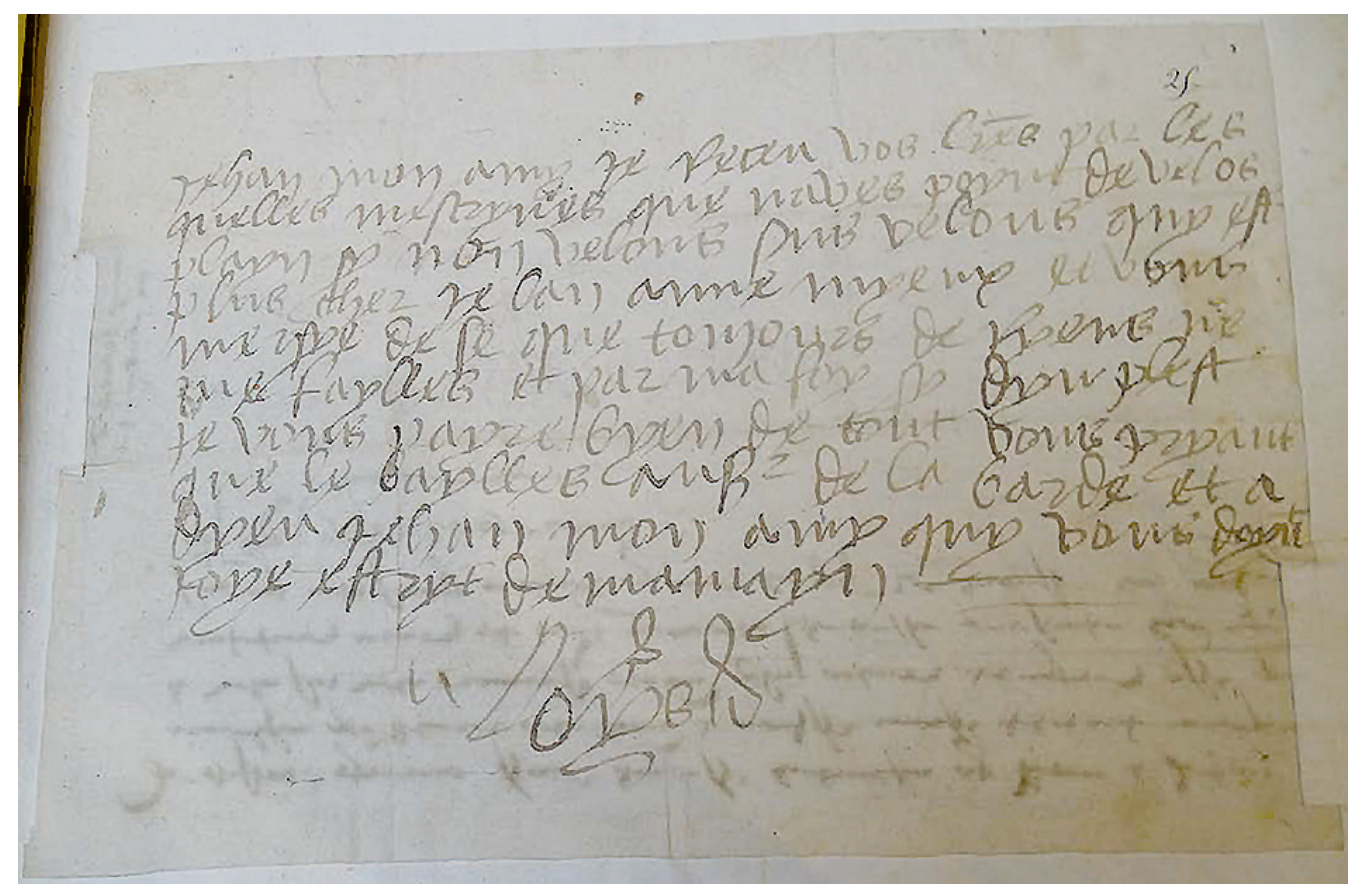

Figure 1. Letter of Louis XI to Giovanni Arnolfini, 1460.

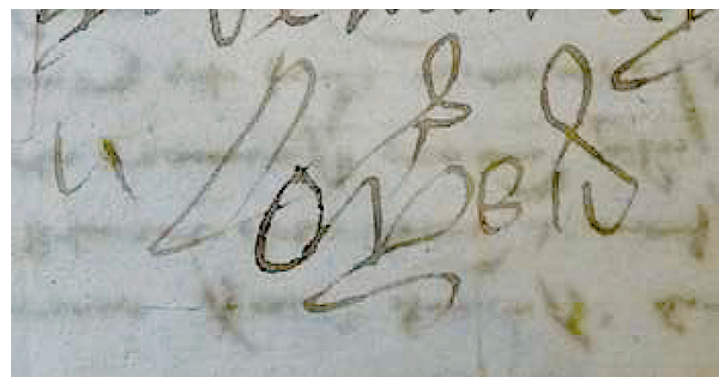

Fugure 2. Letter of Louis XI to Giovanni Arnolfini, 1460. Fragment.

ments ${ }^{20}$; the ends of strokes are sharp, which indicates high speed of writing and automated execution of the signature, without signs of unmotivated stops. The handwriting has a tendency to stretch horizontally. Rounded shapes dominate over direct and angular ones. Lines are located on a sheet almost in parallel to the top and lower cuts of a piece and in general don't tend to rise or lower. As for the signature, it belongs to the category of full-

${ }^{20}$ Connectedness in this case is assessed from the point of view of the Gothic cursive prevalent in France in the $15^{\text {th }}$ century, which required a much more frequent lifting of the writing instrument from the surface of the document compared to modern handwriting, with which forensic handwriting examination has to deal with. Thus, the coherence of Louis XI's handwriting appears to be much higher. 
name transcription "Loys" 21 , and all known samples have such spelling 22 . On the right and the left of a name, there are signs resembling Latin letter " $u$ ". Right " $u$ " is adorned with the loop directed upward. Above the letter " $y$ " is placed an element similar to the connecting union " $\&$ ", but in the mirror image, which acts as a dot over " $y$ "23. The cases when these three signs accompanying the name of the king are absent are known ${ }^{24}$, but they are extremely rare ${ }^{25}$. Thus, Louis XI's signature can be classified as a compound signature which is hard to imitate.

At the same time, candidates for imitators of Louis' signature should be attested as experts of the highest category. All of them are professional scribes with a long-term experience and undeniable skills. Among those who had the privilege to imitate king's signature, Claude Jeay names the following three persons: Nicolas Tilhart, Jean Bourré and Ymbert de Batarnay.

The success of the simulator depends on a number of factors and circumstances. First of all, on the way of imitation of the handwriting of another person. In criminology, where imitation is a common problem related to forgery, two techniques are distinguished: drawing "by eye" (with or without preliminary training) and copying by memory. Both opportunities were available to royal secretaries. They had enough samples of Louis' signatures and an opportunity to observe how the King signed documents. As professionals, they were perfectly capable of reconstructing his signature by the sample and by memorizing characteristic movements.

The imitator's complex of writing motor skills ${ }^{26}$ are of considerable value. They are manifested by the degree of clarity of handwriting, the level of perfection of writing movement, the variety of techniques as well as the structure of handwriting and its originality. Our imitators were more than capable of doing it all. Professional copyists could write in several different handwriting manners ${ }^{27}$. There is no need to prove the high level of clarity and perfection of the system of coordination of handwriting movements which royal copyists obtained: the best evidence of their high skills is the role they played in the government.

Substantial assistance in the analysis of the imitated handwriting is provided by the candidate's samples of calligraphy. Habitual handwriting of the falsifier can be identified in the imitated signatures. In our opinion, the analytical procedure of autographs of Louis XI is unfeasible because the length of texts is so insignificant that it doesn't enable to make any assumptions. (Louis' signatures and signatures of his secretaries share only one letter $)^{28}$.

${ }^{21}$ Pakhomov A. V., Sysoyeva L.A. Sudebno-ekspertnoye issledovaniye sovremennoy podpisi: Uchebnoye posobiye. Moscow, 2007. P. 18; Sysoyeva L. A. Sovremennoye sostoyaniye pocherkovedcheskogo issledovaniya podpisi // Fotografiya. Izobrazheniye. Dokument. 2013. Iss. 4(4). P. 10-14.

22 Jeay C. Signature et pouvoir... P. 166.

${ }^{23}$ See the figures.

24 At least one case contains only the second "u". (BNF. Ms. fr. 2909. F. 14).

25 Jeay C. Signature et pouvoir... P. 172-173.

26 A complex, formed in the process of literacy learning, is called a functional-dynamic complex of writing motor skills. It is implemented by means of the system of movements, specially adapted to it. Rubtsova I. I., Sysoyeva L. A., Korshikov A. P., Yermolova Y. I., Bezrukova A. I. Slovar' osnovnykh terminov pocherkovedcheskoy i avtorovedcheskoy ekspertiz. Spravochnoye posobiye. Moscow, 2008. P. 24.

27 Tsypkin D. O. Ponyatiye pocherka. P. 853-854.

${ }_{28}$ For the signatures of Tilhart and Bourré, see Jeay C. Signature et pouvoir... P. 178, 181, 206, 209, 214-215, and the signature of Batarnay see: BNF. Mrs. fr. 2909. F.33v. 


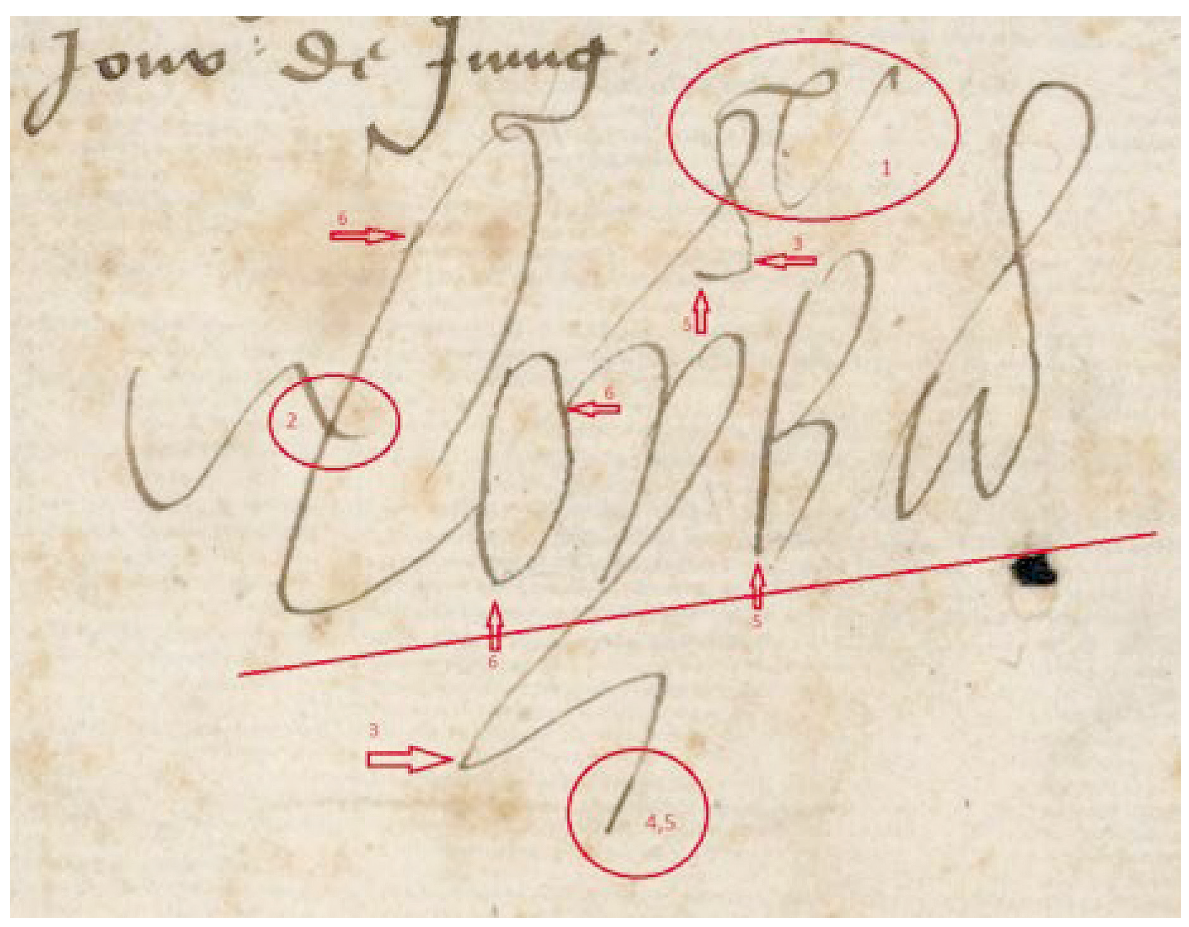

Figure 3. Letter of Louis XI to Galeazzo Maria Sforza, Duke of Milan, 1470. Fragment.

As is often the case in an unusual manner of writing, the automatism of performance suffers the most, and general coordination of movements decreases, while evident signs of imitated handwriting are large and small sinuosity and angularity of strokes, prevalence of adhesions over conjoint elements, thickness at the beginnings and terminations of strokes, unjustified stops of a feather as well as undifferentiated pressing ${ }^{29}$. We will make an attempt to confirm the presence or absence of these signs in the documents from Scientific Archives of St. Petersburg Institute of History.

Conducting the research in a chronological order of the documents will allow us to identify tendencies in the change of handwriting. The very first obvious evidence can be seen in the autograph of 1470 (Fig. 3) and is related to ductus rather than to aforementioned signs: the diacritical sign over " $y$ " has a slightly different form (1).

The next feature that can be observed is the first element of a paraph which intersects the letter "l" (2) that never occurred in other signatures of Louis XI. Moving towards the characteristics of handwriting itself, it is possible to note light sinuosity of lines, but since that can be traced closer to the end of the signature and is rather insignificant, it can be explained by the roughness of paper or the working surface on which the signature was made. The angularity (3) appears in the lower part of the diacritical sign and of the letter " $y$ ". In the same place the obvious slowing down of the movement is observed in the thickening of a stroke (4). The blunt endings (5) are noticeable in the letters " $y$ " and "s" and in the diacritical sign. The points of the beginning of the elements in the letter are not as

${ }^{29}$ Sudebno-pocherkovedcheskaya ekspertiza: osobennaya chast'. Issledovaniye rukopisnykh tekstov. Moscow, 2007. P. 253. 


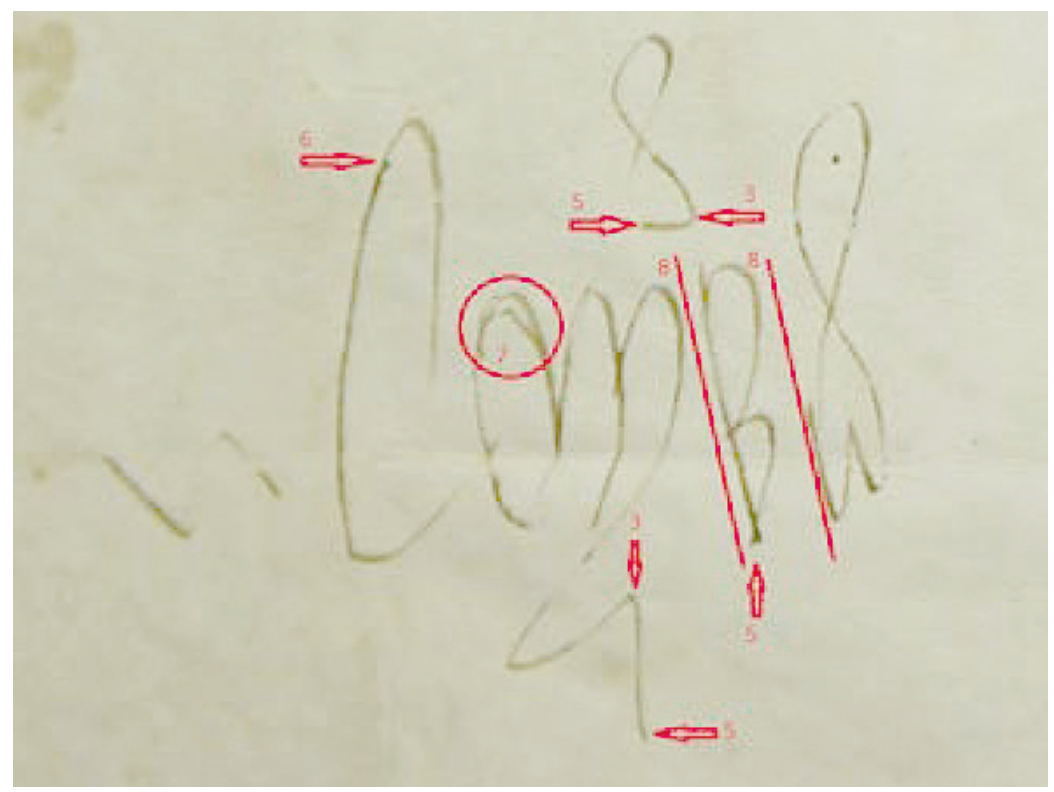

Figure 4. Donation of territories of Talmont and others to Philippe de Commynes, 1472. Fragment.

natural and careless as in the sample but, instead, are neatly adjoined to the already made strokes (6). In the act in favor of Philippe de Commines (1472) similar features (Fig. 4) are shown.

Traces of corrections (7) are observed in the letter "o". Besides, two last letters have an inclination (8) to the left, which was typical of Gothic cursive ${ }^{30}$. In the writing style of the following two documents (Fig. 5,6) a tendency to angular forms is observed, as well in the letters "l" and "o", which is not a regular case.

Uncertainty of the feather results in slightly sinuous lines (9). Finally, in the last document (Fig. 7) the letter "s" has a rounded shape, but the angularity appears not only in the last, but also in the first element of the letter " $y$ ".

As it has been noted above, possible candidates who might have produced the investigated signatures had advanced writing skills. So, we shouldn't expect them to make obvious mistakes. To sum up observations, it is possible to notice that the angularity of strokes gradually increases, though as we have pointed out rounded shapes were characteristic of Louis XI's handwriting. Either way, the blunt endings which demonstrate the loss of handwriting fluency are observed in all five samples. An important factor is that the signatures are larger by the size than the signature in the sample. In the imitated handwriting, the length of horizontal and vertical movements increases, because the attention is paid to letters, and control over the general location of the signature in space can be lost. Lastly, the rising movement that isn't observed in the sample, is characteristic of all five researched signatures. Thus, we can conclude that there is a high probability that none of the five signatures is an autograph of King Louis XI.

${ }^{30}$ Malov V.N. Proiskhozhdeniye sovremennogo pis'ma. Paleografiya frantsuzskikh dokumentov kontsa XV - XVIII v. Leningrad, 1975. P.32-35. 


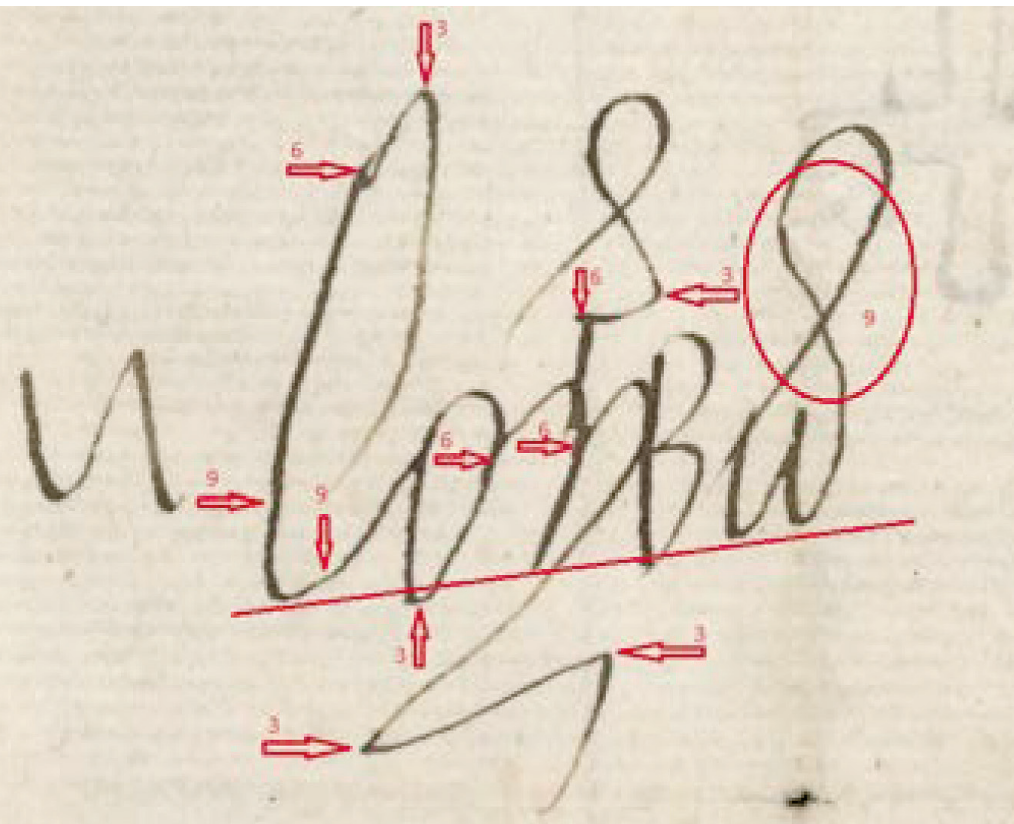

Figure 5. Letter of credence for Jean de Daillon and others, 1475. Fragment.

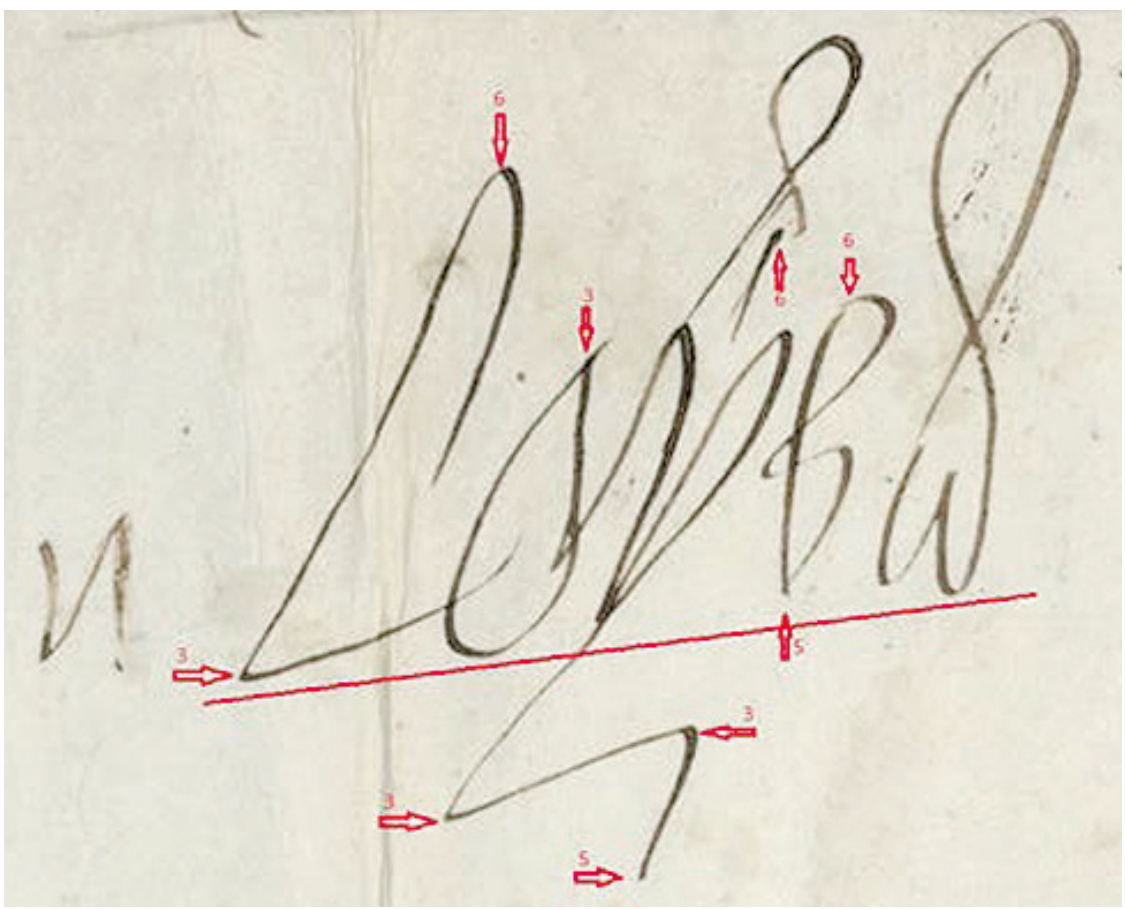

Figure 6. Donation of seigneurie of Pontarlier to Robert de Montgombry, 1479. Fragment. 


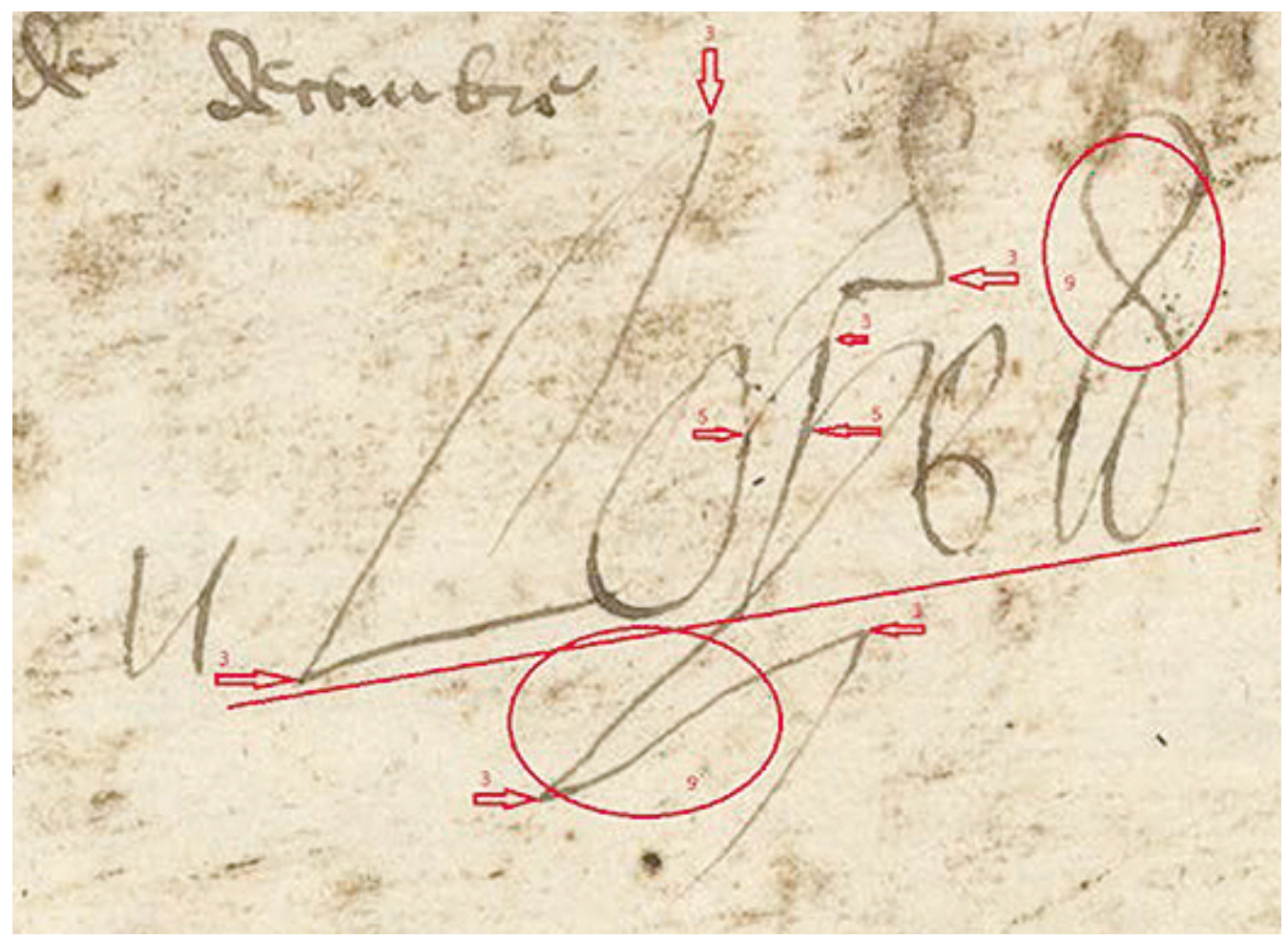

Figure 7. Letter to seigneur du Lude, Governor of Daphiné, 1480. Fragment.

As a counterargument, it is possible to assume that the sample and the examined signatures are separated by a 10-year-time gap spread approximately. In fact, with the passing of time, the handwriting can change. However, if we are to consider the already formed writing style of a person who has finished his education, then it is possible to conduct the research based on the samples which aren't related to the same time of the studied documents. The gap in 10-20 years doesn't interfere with the identification if the handwriting hasn't changed under the influence of any disease ${ }^{31}$, but there are no evidence that Louis XI had been wounded or had suffered from any serious illness before $1481^{32}$.

Finally, two more autographs of Louis XI were discovered on the website of antiquarian company "Piasa" 33 . They contain, besides the signature, 2 and 5 lines written by Louis XI himself, according to the experts of the antiquarian house and Claude Jeay ${ }^{34}$. Conducting a comparison of these letters with those of 1460, it is hard to deny the obviously

31 Sudebno-pocherkovedcheskaya ekspertiza... P. 48.

32 Blanchard J. Louis XI. Paris, 2015. P. 252.

${ }^{33}$ Lot 135 - Louis XI (1423-1483). L.S. avec 2 lignes autographes, Orléans 18 avril 1466 URL: http://www.piasa.auction.fr/_fr/lot/louis-xi-1423-1483-l-s-avec-2-lignes-autographes-orleans-18-avril1466-a-869642\#.WhyOI_ll_IU (accessed 12.12.2017); Lot 571 — Louis XI (1423-1483) Roi de France. L.S. avec 5 lignes autographes. URL: http://www.piasa.auction.fr/_en/lot/louis-xi-1423-1483-roi-de-france-l-savec-5-lignes-autographes-hellip-919711\#.WhySRfll_IU (accessed 12.12.2017).

34 Jeay C. Signature et pouvoir... P. 220. 
similar roundish handwriting, and a note "is written by my hand" left on both samples ${ }^{35}$. Unfortunately, low resolution of photos prevents us from the meticulous analysis. Nevertheless, both documents confirm the stability of the king's handwriting as one document is dated April 18, 1466, and the second - April 24 without indication of the year. As the document is written in Tours, most probable date is $1465^{36}$. In both signatures there are no sharp broken lines. The signature's size doesn't increase, as far as it is possible to judge in comparison with the sample. The position of lines remains horizontal, and only in the Piasa document, lot 571, we observe insignificant rising of a line. This stability, in our opinion, confirms the conclusion that large signatures, which extend vertically and tend to have angularity and distinctly visible rising direction of lines, can't have been made by Louis XI's hand ${ }^{37}$.

Applying methods of forensic handwriting examination helps to strengthen analytical part of comparison of signatures and to complement traditional arsenal of tools of palaeography, significantly expanding the number of parameters in which the handwriting can be described. The photo tables with markings by arrows, commonly used by handwriting experts, makes the system of proofs much more evident, drawing the attention of the reader to characteristic elements of handwriting, technically facilitating the proof of identity or distinction of signatures.

In some cases, forensic handwriting examination offers not only methods, but interpretations as well. For example, Claude Jeay notices a steady tendency for the signature to increase in size: during Louis XI (1461-1483) reign his signature had increased from 15 to $50 \mathrm{~mm}^{38}$. Claude Jeay offers a graphological interpretation and concludes that the signature increase symbolized the strengthening of the power of the monarch who had made a long way from being an outcast dauphin fleeing from his father's anger to the lands of his vassal, the Duke of Burgundy, to becoming the "spider king" who concentrated all threads of the power in his hands. For our part, we can also add that this phenomenon can be explained by the increase in the share of the signatures made by secretaries, as the imitation of writing of the other person leads to the stretching of letters horizontally and vertically.

${ }^{35}$ In the case of Lot 571 , the abundance of abbreviations is confusing because the abbreviations were not typical of Louis XI. However, the texts are so different that they do not enable us to compare the abbreviation. In addition, in the end there is a double slash, as is customary in the literary and clerical writing, whereas in the sample letter of Louis XI we see a double horizontal line. Marchello-Nizia Chr. Ponctuation et " unités de lecture " dans les manuscrits médiévaux, ou : je ponctue, tu lis, il théorise // Langue française. 1978. N.40. P.32-44 ; Lavrentiev A. Ponctuation française du Moyen Âge au XVIe siècle: théories et pratiques // La ponctuation à l'aube du XXI siècle. Perspectives historiques et usages contemporains / sous la dir. de S. Pétillon, F. Rinck, A. Gautier. Limoges, 2016. P. 39-62.

36 According to Louis's correspondence, he was in Tours on April 24 in 1465. Lettres de Louis XI. Vol. 2. P.278. In addition, the letter mentions certain «insurgents and defiant» («noz rebelles et desobeissans»). That was how Louis usually called the princes of blood, who united against him in the League of the Public Weal. On March 10, 1465, the League published its manifesto against Louis XI, which he considered insubordination and insurrection against his authority. For details, see Nosova E. I. Burgundiya protiv Frantsii: rol' aktovogo materiala v konstruirovanii identichnosti // Dialog so vremenem. 2017. Vol.60. P.277-287.

37 Another autograph, showing similar elements, was found on the site of the antique house Brissonneau on the marriage contract attested by Louis XI. Lot 24. Louis XI 1461. URL: http://www.brissonneau. net $/ \mathrm{html} /$ fiche.jsp?id=650457\&np=\&lng=fr\&npp=10000\&ordre $=\& a f f=\& r=($ accessed 12.12.2017).

38 Jeay C. Signature et pouvoir... P. 189. 
In addition, forensic handwriting expertise allows not only to recheck the data obtained on the basis of palaeography and offer a different interpretation, but also to refute some conclusions. Thus, palaeography, which was initially linked with the calligraphic writing of professional copyists, has generated a statement that monarchs wrote badly ${ }^{39}$. Of course, if their autographs will be compared with the calligraphic writing style, where not only legibility of handwriting, but also its harmony was taken into account, then the royal handwriting can seem awkward and not esthetic. However, it is possible to say that Louis XI's writing style is a mature one: his writing skills were developed, and he often practiced them. At the end of the 19th century it was noticed by publishers of Louis XI's correspondence $^{40}$, and then many other authors repeated that observation ${ }^{41}$. Nevertheless, often the signature is attributed to the monarch because it is "bad". In accordance with handwriting examination logic, such arguments as trembling of a feather and uncertainty of movements should be put down rather to the break of automatism, which, on the contrary, serves as proof that the signature doesn't belong to the king. It is on the basis of these arguments that the corpus of already known autographs of the king must be revised: many of them could have been made by his secretaries. The change in the set of samples may, in its turn, lead to a revision of the conclusions about the authorship of the other signatures which were earlier considered as autographs.

\section{References}

Blanchard J. Louis XI. Paris, Perrin Publ., 2015, 371 p.

Burdanova V.S., Sysoyeva L.A., Tsypkin D.O. K voprosu ob istorii russkoy podpisi. Vestnik SanktPeterburgskogo universiteta MVD Rossii, 1999, no. 1, pp. 118-121. (In Russian)

Fraenkel B. La signature : genèse d’un signe. Paris, Gallimard Publ., 1992, 150 p.

François M. Les signatures de Louis XI. Bulletin philologique et historique, 1959, pp. 221-230.

Jeay C. Signature et pouvoir au Moyen Âge. Paris, École des chartes Publ., 2015, 608 p.

Lassalmonie J.-Fr. La boîte à l'enchanteur: Politique financière de Louis XI. Vincennes, Institut de la gestion publique et du développement économique, Comité pour l'histoire économique et financière de la France Publ., 2002, 860 p.

Lavrentiev A. Ponctuation française du Moyen Âge au XVIe siècle: théories et pratiques. La ponctuation à l'aube du XXI siècle. Perspectives historiques et usages contemporains. Éd. par S. Pétillon, F. Rinck, A. Gautier, Limoges, Lambert-Lucas Publ., 2016, pp. 39-62.

Malov V.N. Proiskhozhdeniye sovremennogo pis'ma. Paleografiya frantsuzskikh dokumentov kontsa XV XVIII v. Leningrad, Nauka Publ., 1975, 199 p. (In Russian)

Marchello-Nizia Chr. Ponctuation et « unités de lecture » dans les manuscrits médiévaux, ou: je ponctue, tu lis, il théorise. Langue française, 1978, no. 40, pp. 32-44.

Morel O. La grande chancellerie royale et l'expédition des lettres royaux de l'avènement de Philippe de Valois à la fin du XIV siècle (1328-1400), Paris, A. Picard et fils Éditeurs Print., 1900, 592 p.

Nosova E. I. Burgundiya protiv Frantsii: rol' aktovogo materiala v konstruirovanii identichnosti. Dialog so vremenem, 2017, vol. 60, pp. 277-287. (In Russian)

Nosova E. I. Chartes et lettres inédites de Louis XI (1461-1483) aux Archives de l'Institut d'histoire de SaintPétersbourg. Bulletin de la Société de l'histoire de France, An. 2014, pp. 41-68.

Pakhomov A. V., Sysoyeva L. A. Sudebno-ekspertnoye issledovaniye sovremennoy podpisi: Uchebnoye posobiye, Moscow, EKTS MVD Rossii Press, 2007, 60 p. (In Russian)

Rubtsova I. I., Sysoyeva L. A., Korshikov A. P., Yermolova Y. I., Bezrukova A. I. Slovar' osnovnykh terminov pocherkovedcheskoy i avtorovedcheskoy ekspertiz. Spravochnoye posobiye. Moscow, EKTS MVD Rossii Press., 2008, 64 p. (In Russian)

${ }^{39}$ For example, J. Blanchard, the author of the latest biography of Louis XI, points out that he wrote with ease in comparison with other princes' handwriting. Blanchard J. Louis XI... P. 188.

40 Lettres de Louis XI. Vol. XI. P. V.

41 Thibault M. La Jeunesse de Louis XI (1423-1445). Paris, 1907. P. 121. 
Schreurer R. L'enregistrement à la chancellerie de France au cours du XVe siècle. Bibliothèque de l'École des chartes. 1962 , no. 120 , pp. 104-129.

Sysoyeva L.A. Sovremennoye sostoyaniye pocherkovedcheskogo issledovaniya podpisi. Fotografiya. Izobrazheniye. Dokument, 2013, iss. 4(4), pp. 10-14. (In Russian)

Sysoyeva L.A., Tsypkin D. O. Yeshche raz k voprosu o sovremennykh issledovaniyakh podpisi. Ekspertkriminalist, 2016, no. 2, pp. 22-24. (In Russian)

Tessier G. Diplomatique royale française, Paris, Éditions A. et J. Picard Print., 1962.

Thibault M. La Jeunesse de Louis XI (1423-1445). Paris, Perrin Éditeurs Print., 1907, 654 p.

Tsypkin D. O. Na puti k yedinomu ucheniyu o pocherke. Biblioteka kriminalista. Nauchnyy zhurnal, 2016, no. 3(26), pp. 349-361. (In Russian)

Tsypkin D. O. Neskol'ko predvaritel'nykh zamechaniy o yedinstve ekspertnoy nauki i o problemakh sovremennogo istochnikovedeniya. Fotografiya. Izobrazheniye. Dokument, 2012, iss. 3(3), pp. 3-7. (In Russian)

Tsypkin D. O. Ob izuchenii istoricheskogo pis'ma na kafedre istorii zapadnoyevropeyskoy i russkoy kul'tury Instituta istorii SPbGU. Istoriya i kul'tura. Issledovaniya. Stat'i. Soobshcheniya. Publikatsii, iss. 14(14). St. Petersburg, St. Petersburg University Press, 2016, pp. 226-236. (In Russian)

Tsypkin D. O. Ponyatiye pocherka v izuchenii russkogo istoricheskogo pis'ma: K probleme razrabotki metodologii pocherkovedcheskogo analiza drevnerusskikh rukopisey. Trudy Otdela drevnerusskoy literatury. Vol. 64. St. Petersburg, Rostok Publ., 2016, pp. 836-881. (In Russian)

Tsypkin D. O. Problema razrabotki yedinoy metodologicheskoy sistemy identifikatsii pishushchego v izuchenii drevnerusskikh rukopisno-knizhnykh pamyatnikov (na materiale Sofiyskogo, Kirillo-Belozerskogo i Solovetskogo sobraniy OR RNB. Istoriya i kul'tura. Stat'i. Issledovaniya. Soobshcheniya, iss. 11. St. Petersburg, St. Petersburg University Press, 2013, pp. 225-242. (In Russian)

Received: 15.12.2017

Accepted: 30.03.2018 